\title{
Wikipedia and Its Sister Projects as Important Elements of the Teaching and Learning Process - a Review of the Global Situation
}

\author{
Wikipedia i jej projekty siostrzane jako \\ ważne elemety procesu nauczania \\ i uczenia się - przeglad sytuacji na świecie
}

\section{Introduction}

Competences of the future are often equated only to digital: technological virtuosity is to be the guarantor of the well-being of individuals as well as entire educational and cultural institutions, etc. However, in-depth reports based on multi-threaded analyzes show that focusing only on digital will not fulfill the demands of effective and at the same time attractive lifelong education. It is also necessary to practice cooperation skills, operate in an interdisciplinary environment, jointly define goals and critically evaluate information through the exchange of knowledge.

Such criteria can be found in the project activity demonstrated by the Wikipedia community and its sister projects (i.e. Wiktionary, Wikisource, Wikimedia Commons, Wikidata and others) around the world. Endless possibilities of raising various competences can be seen during training courses on editing, hackathons, cooperation with museums, libraries as well as schools and universities.

In activities emphasizing the impact of wise use and reliable content creation of Wikipedia resources on the development of digital competences and media literacy, the Wikimedia Education movement plays an important role. 
The mission and idea of Wikimedia Education are described in the following words:

We believe Wikipedia belongs in education. When students of all ages contribute to Wikimedia projects as part of their learning, they gain significant 21st century skills. By fostering a relationship between Education and the Wikimedia movement, we have the best chance to realize our goal that the sum of all knowledge will be accessible to everyone in the world for free.

Nowadays, Wikimedia Education local coordinators organize, support and coordinate dozens of initiatives in the spirit of open education and free knowledge. This text aims to bring the reader closer to the educational enthusiasm and professionalism of Wikipedians in Serbia, Germany, the United States, and Poland.

\section{Bibliography}

Gray, P. (2017). Differences Between Self-Directed and Progressive Education. Psychology Today, 06.27.2017. Obtained from: https://www.psychologytoday.com/us/blog/ freedom-learn/201706/differences-between-self-directed-and-progressive-education.

Nattoo R. 6 Key Trends to 21st Century Teaching, EdSurge. Obtained from: https://www.edsurge. $\mathrm{com} /$ research/guides/21st-century-teaching-guide.

Tomczyk, Ł. (2020). Skills in the Area of Digital Safety as a Key Component of Digital Literacy Among Teacher. Education and Information Technologies, 25, 471-486.

Wikimedia Education: https://outreach.wikimedia.org/wiki/Education/About.

\section{Nebojša Ratković}

nebojsa.ratkovic@vikimedija.org

Wikipedia Education Program in Serbia

Wikimedia Serbia

Serbia

\section{Wikipedia Education Program in Serbia and Professional Development for Teachers Project}

Good practice in the implementation of the Wikipedia Education Program in Serbia is reflected in the increasing number of educational institutions interested in introducing this modern approach in teaching. Since 2005, when the Wikipedia education program was implemented in Serbia for the first time, the number of educational institutions involved in the project has grown progressively. In 2020 
that number has reached 58 primary schools, secondary schools and faculties involved in the Wikipedia in schools project and 37 schools as a part of the professional development of the teachers project. Over 5.800 students have undergone the training, and they have edited over 6.700 Wiki pages.

Through a questionnaire filled out by 250 students from the University of Belgrade and the University of Niš during the 2018/2019 school year, Wikimedia Serbia obtained the results that speak about students' opinion regarding the implementation of Wikipedia in schools project. In $62 \%$ of the cases, students stated that the information they heard during the Wiki workshops were very useful, while $60 \%$ of the participants con-

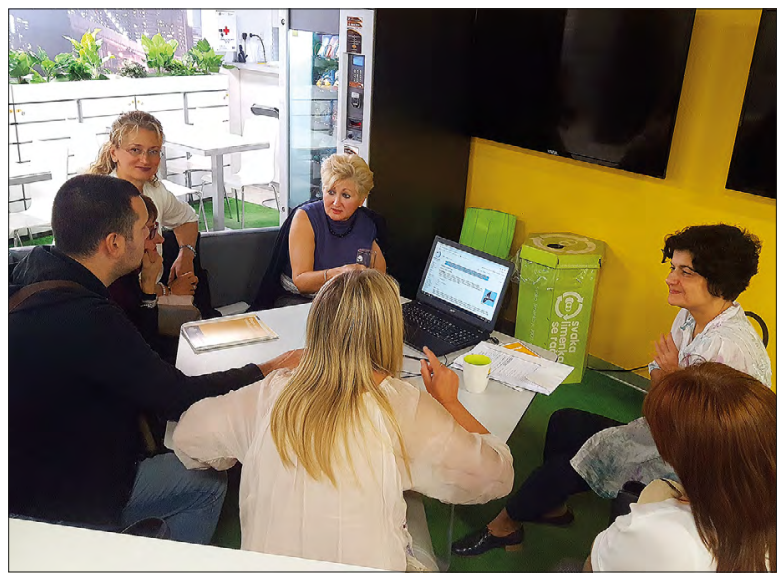

Photo 1 Accredited Wikipedia course for teachers in Belgrad (2018) sidered the topic covered to be very useful. As many as $55 \%$ of students stated that the Wiki workshops should be held on a full-time basis, and $44 \%$ said that training should be held periodically. Students' comments in this questionnaire most often referred to the positive experience during the workshops, the expertise of the facilitators, the importance of the information, and the practical skills they got. The lowest grades were given to the technical conditions at the faculties where the workshops took place, the technical equipment of the computer rooms and the Internet speed. The results of this evaluation clearly demonstrate the students' satisfaction with the program and its suitability to their needs.

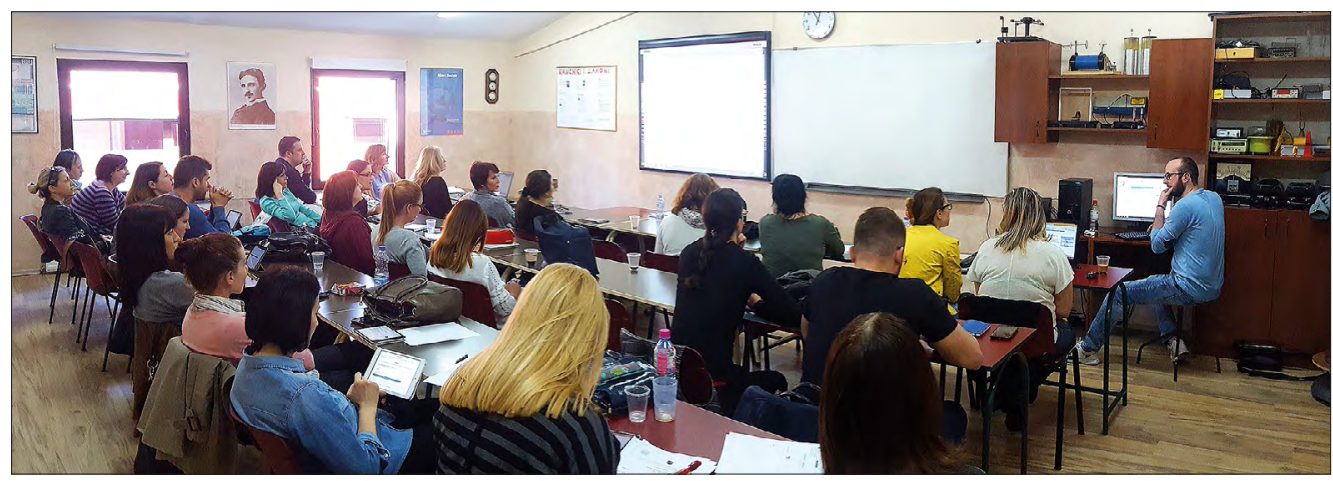

Photo 2 Accredited Wikipedia course for Serbian teachers (2018) 
The main objectives of the Wikimedia Serbia are to improve the competencies of teachers in the application of new and open learning platforms based on wiki tools and to improve the quality of the teaching and educational process. To reach these goals, Wikimedia Serbia has created the seminar titled

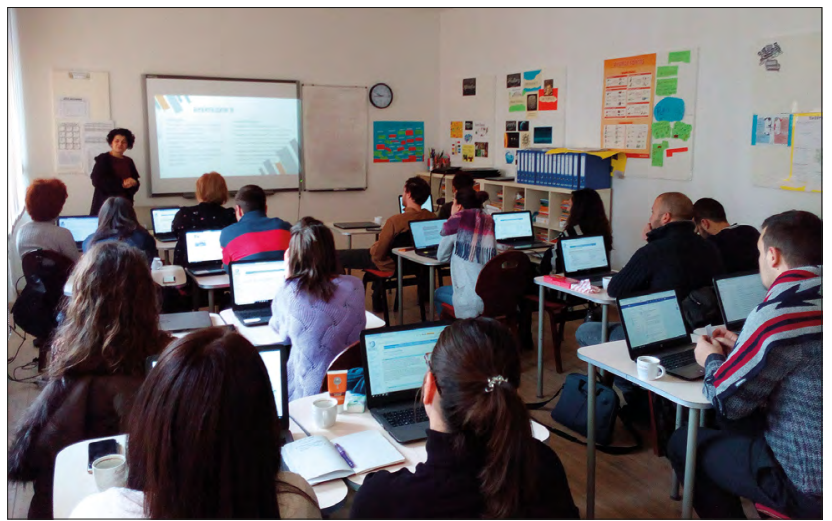

Photo 3 Accredited Wikipedia course for Serbian teachers (2018) Application of Online Wiki Tools in Teaching and Learning which is accredited by the Institute for the Education Improvement (founded by the Ministry of Education) for the period of three school years: 2018/2019, 2019/2020 and 2020/2021 (Institute for Education Improvement of the Ministry of Education, 2018, Catalog of professional development programs for school years 2018/2019. 2019/2020 and 2020/2021).

It is intended for teachers of general and professional subjects in high schools and secondary vocational schools as well as teachers of higher grades of primary school. The seminar lasts eight hours and is divided into a theoretical and practical part. During the theoretical part, the participants have the opportunity to learn more about the following topics: the basic principles of Wiki projects, examples of good practice of using Wikipedia in educational processes, wiki tools, application of Wikipedia and related Wiki projects of free teaching knowledge (Ratković, Stakić, Maljković 2019).

The practical part involves acquiring knowledge and developing skills for creating new or editing existing articles in Wikipedia. The work does not require programming skills and the seminar is designed so that teachers can apply acquired skills in the classroom immediately after completion. The seminar carries eight points for compulsory professional development. After the seminar, the participants receive a certificate of attendance and further support of the team of Wikimedia Serbia in the realization of the learned in practice. The seminar is free of charge for all participants.

Seven lecturers are hired for the realization of the seminars, while four of them are also the authors of this project. Among them is the author of this article, Nebojša Ratković, who is also employed at Wikimedia Serbia as Education program manager.

For the purposes of this analysis, Wikimedia Serbia collected data using a questionnaire created for the purpose of evaluation of the seminars by the Institute. The analysis was conducted on a sample of 532 participants from 35 
different schools who attended at least one of the 25 seminars held by Wikimedia Serbia between November 2016 and December 2018 (Web portal for seminars of Wikimedia Serbia, 2019). Wikipedia education program team used the method of content analysis to process the collected answers to open questions.

The general impression is that a seminar is needed. By analyzing the questionnaires filled out by the participants at the end of the seminar, the majority agreed that the topics discussed at the seminar are clear, gradually introduced into matter and that they develop awareness for their work to be more innovative and interactive through the use of wiki tools in teaching. The overall impression is that the seminars have passed in a great atmosphere of cooperation and learning and that the teachers will continue their further training in the field of application of new and open learning platforms based on wiki tools.

The seminar focused on the exchange of experience and knowledge in working with students, and during the seminars the participants have an opportunity to talk about possibilities for using online wiki tools in the classroom for active discussion and asking questions and suggested their ideas on raising information literacy among students. During the seminars, the lecturers checked the knowledge that the participants learned through the practical work, and the participants had the opportunity to present their impressions about the seminar. Their comments were more than positive and mainly focused on the organization of seminars, lecturers and the effects of the entire project of professional development of teachers.

From this, Wikimedia Serbia have concluded examples of good practice that consist of the following (Ratković, Stakić, Maljković 2019):

1. If some of the teachers want to apply in practice the knowledge gained from the seminar, it is necessary to explain them the procedures that are important for the successful implementation of the project. Experience has shown that it is good to hold another additional meeting with these teachers to get adequate information about the procedures.

2. Participants should receive maximum feedback from Education program manager of Wikimedia Serbia and the materials from the seminar immediately after its completion.

3. All the conclusions reached during the seminar should be recorded.

4. Organizing a meeting by Education program manager with the management of the institution is always a recommendation and can be of great value, especially when the project is being implemented for the first time, because it makes a significant contribution to the entire process. An example that in our opinion positively reflects the realization of the program's effects in practice is the example of the elementary school "Jovan 
Sterija Popović" in Belgrade. After two seminars held in this school, teacher Sanja Ječmenica showed great interest in implementing the project Wikipedia in schools. After the seminar, Education program manager of Wikimedia Serbia held a meeting together with school director in order to plan activities and arrange cooperation. Training was held for students of 6th grade on the editing Wikipedia. The activities were realized within the timeframe, and the students wrote the articles in pairs or in groups of three. For this activity, Sanja won the third place for Digital Class at a competition organized by the Ministry of Trade, Telecommunications and Tourism of the Republic of Serbia in 2018. The prize is awarded to those professors who profusely use modern information technologies in their teaching practice (Ministry of Education, Science and Technological Development, (2019) Decision on the selection of programs of national significance for education and training that will be allocated financial funds for realization of activities in 2018/2019).

Participants of the seminar are satisfied with the cooperation with Wikimedia Serbia and believe that Wikipedia can be used in teaching at various levels. They have come to the conclusion that the dramatic lack of information literature can be replaced by making the content and articles in Wikipedia, and that Wikipedia encourages students to develop technical and communication skills, as well as forming a neutral point of view. It is particularly positive it is noticed that students with much greater responsibility and more motivation are approaching the creation of their own works when they know their work will be public and accessible to all. Therefore, it can be concluded that the result of the seminar are many and that they are related to the field of knowledge and the field of skills and teaching.

Translated by Author

\section{Bibliography}

Institute for Education Improvement of the Ministry of Education (2018). Catalog of Professional Development Programs for School Years 2018/2019, 2019/2020 and 2020/2021. Obtained from: https://zuov.gov.rs/katalog-programa-strucnog-usavrsavanja-za-skolsku-2018-2019-2019-2020-i-2020-2021-godinu/.

Ministry of Education, Science and Technological Development (2019). Decision on the Selection of Programs of National Significance for Education and Training that will be Allocated Financial Funds for Realization of Activities in 2018/2019. Obtained from: http://srpskipariz.weebly.com/ uploads/5/8/2/1/58212517/lista_nagradjenih_radova_na_konkursu_2018-19_-_za_sajt.pdf. 
Ratković, N., Stakić, D., Maljković, F. (2019). Desenvolvimento profissional de professores - o exemplo do curso credenciado da Wikimedia Sérvia/Professional Development of Teachers - Example of Accredited Seminar of Wikimedia Serbia. Prisma.Com, 40, 125-134.

Web portal for seminars of Wikimedia Serbia: http://seminari.wikimedia.rs/index.php/English. Wikimedia Education - Serbia: https://outreach.wikimedia.org/wiki/Education/Countries/Serbia.

\section{List of photographs}

Photo 1 Accredited Wikipedia course for teachers in Belgrad (2018). Neboysha87 / CC BY-SA (https://creativecommons.org/licenses/by-sa/4.0).

Photo 2 Accredited Wikipedia course for Serbian teachers (2018). Neboysha87 / CC BY-SA (https://creativecommons.org/licenses/by-sa/4.0).

Photo 3 Accredited Wikipedia course for Serbian teachers (2018). Neboysha87 / CC BY-SA (https://creativecommons.org/licenses/by-sa/4.0).

\section{Wikimedia Education. The Situation in Germany}

The coordination of the educational and cultural promotion of the German-language branch of Wikimedia is partly administered by Wikimedia Deutschland - Gesellschaft zur Förderung des freien Wissens e.V. At present, the department responsible for education, science \& culture has a staff of fourteen (see Wikimedia Deutschland 2020a).

In recent years, several studies have been published on the creation of Open Educational Resources (OER), working methods, free licenses and diversity issues, aimed at supporting cooperation on Wikimedia platforms (Outreach Wiki 2018). Due to the shared language, there is an overlap regarding volunteer responsibilities and projects between German, Austrian and Swiss societies (e.g. Buchem et al. 2015), which in the past also led to a funding of German projects through Austrian and Swiss funding mechanisms. In general, it can be observed that German-language educational and cultural initiatives are continuously carried out in partnership with other organizations. These may be either established sponsors with technical, content-related or administrative knowledge, such as universities, galleries, libraries, archives, museums 
or adult education institutions, or foundations and associations whose aims overlap with the global or local objectives of Wikimedia.

The Open Knowledge Foundation Germany (OKFG) stands out as a recurring,

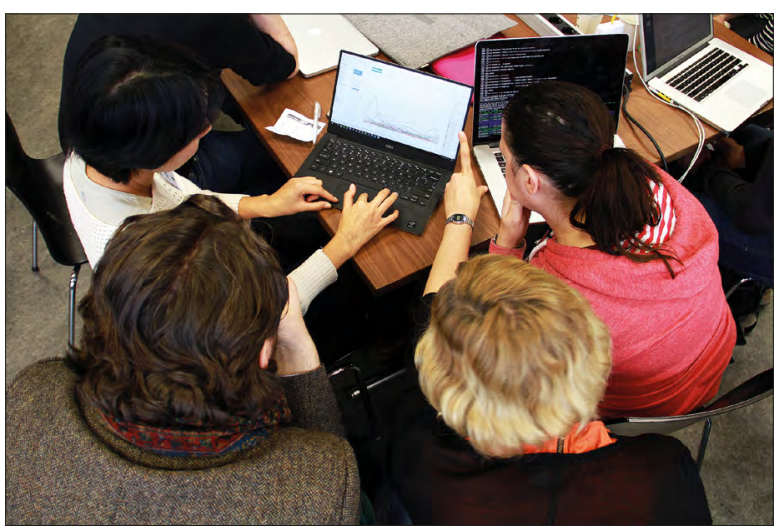

Photo 1 Participants of the Coding DaVinci 2017 event (2017)

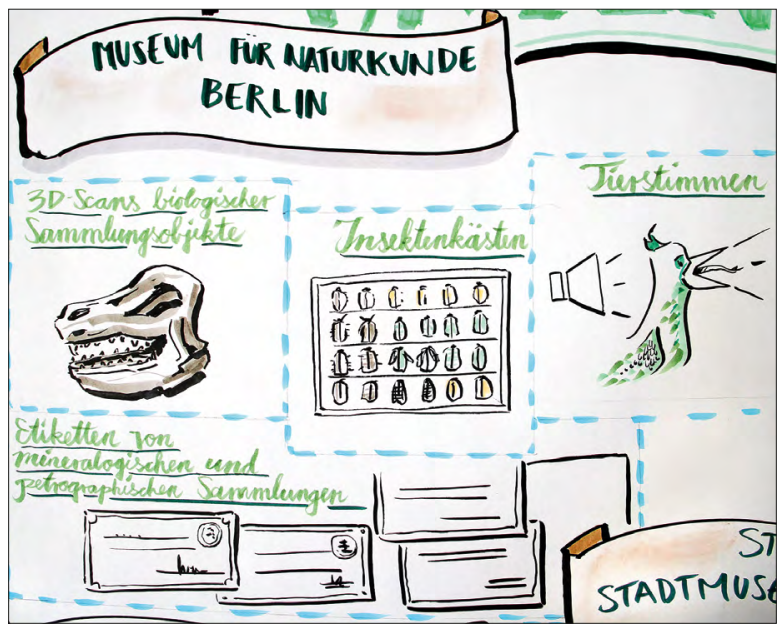

Photo 2 Sketchnote for the Natural History Museum, Berlin at the Coding DaVinci 2017 event (2017) symbiotic partner. As a result, these projects have a greater reach, allowing to simultaneously address several target groups. One such project focused on participating in the Science Year 2014 and in the exhibitions on board the "MS Wissenschaft". Based on experiences gained from previous activities (cf. Meta 2013), both temporary and long-term measures have been taken to encourage underrepresented user groups to increase their participation.

The "Silver Knowledge" project, for example, provided senior citizens with the skills needed to independently transfer knowledge to the Wikimedia portals (Schmidt 2013); the Women Edit project, initiated in 2013, brought together women's initiatives and professional societies and is being continued with the joint production of contributions in so-called "Edit-athons". By participating in calls for proposals for research and development, Wikimedia Germany can repeatedly draw on funding from the European Union (EU) and federal ministries.

Various formats currently form the core of the efforts for Wikimedia Education in Germany: as such, the Bündnis Freie Bildung is an alliance of public institutions, associations, civil society groups and individuals who collect and create free educational resources for all qualification levels and set suitable political and technical framework conditions. The specific work groups are freely accessible via the Slack messaging service, and meetups and conferences provide physical contact points (Bündnis Freie Bildung 2020). 
The Open Science Fellows Program, implemented in 2016, gives up to 20 doctoral students, post docs, junior professors and scientists each year the opportunity to advance and document their research under the Open Science premise. To this end, the selected established scientists or science coordinators are provided with mentors; furthermore, partner organizations, such as university libraries, university computer centers, or museums, train them in the use of the tools and methods available and promote dissemination of research results to the public and to relevant scientific institutions. Travel and accommodation costs linked to the fellowship will be covered. In addition, the scientists selected will receive financial support of 5000 euros for their research projects. The program is financed by the Stifterverband für die Deutsche Wissenschaft, an association of philanthropic foundations, private individuals and companies, and the Volkswagen Foundation.

With its GLAM on Tour program, initiated in 2013, Wikimedia Germany has brought together active users of all the different Wiki projects and curators and staff of galleries, libraries, archives, and museums throughout Germany, in order to secure and expand inventories and important background information through direct contact (Wikipedia 2020). By visiting the institutions, the volunteers from Wikimedia, on the one hand, give the hosts a feel for how to collect and pass on "free knowledge" and, on the other, they can help with the implementation of projects. At irregular intervals and by bilateral agreement, some of the volunteers may remain on site as Wikimedians-in-Residence for a fixed period of time to provide support for long-term projects in the respective institution. This approach seems particularly suitable for regional or rural projects

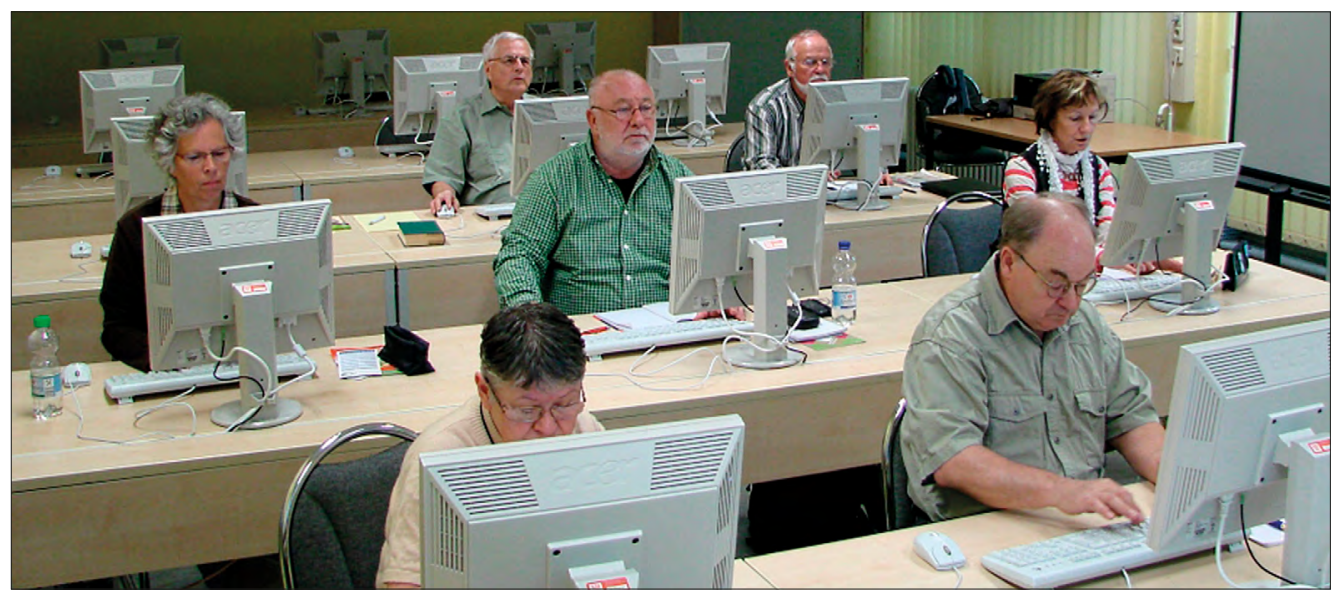

Photo 3 Seniors at the wiki-workshop in Cottbus. Silver Knowledge project (2017) 
in which local structures are not yet self-supporting or which were actually triggered by the visit. Its applicability in processes of structural transformation through decarbonization and social upheaval needs to be discussed separately.

The Coding da Vinci program, implemented in 2014, aims at furthermore processing the data obtained through GLAM-Tours in the course of so-called "culture hackathons", creating small applications such as data visualizations, which often serve as a basis for further use. In contrast to classical hackathons, these are designed for a time frame of several weeks or even months, thus allowing for complex projects to be realized (Wikimedia Deutschland 2020b). At the end of 2019, a scholarship program was implemented to support participants in the implementation (Bergmann 2020).

In the traditional perception, the projects Wikiversity, Wikibooks and Wikisource are above all intended for educational practice. Since 2013, the German-language Wikiversity has been offering a university program, supervised on a voluntary basis, that accompanies lecturers and courses at the respective institution and introduces students to editing (Wikiversity 2020). By 2018, it comprised already 49,011 articles, showing that this number has risen almost linearly since its foundation. While the number of edits fluctuates strongly, the number of active users has decreased by 9 percent compared to the previous year (WikiStats 2019), a progression that mirrors the development of the English-language version. The fact that the number of "very active" users has almost doubled, whereas the number of new users has halved is not only an indicator of the platform's persuasive power, it also shows the need for action with regard to attracting new users. This is also confirmed by the numbers for German-language Wikibooks, which shows stagnating usage figures. Thus, the number of new articles (books) hardly increased at all between 2017 and 2018 (WikiStats 2019). The number of hits, at just under three million hits per month, is fifteen times higher than that for Wikiversity. By contrast, the number of accesses to and edits of Wikisource, which collects public-domain historical publications and primary sources, is on the rise (WikiStats 2019).

All these projects and programs initiated by Wikimedia Germany indicate that increasing priority is given to promoting the linking of and automated approach to knowledge processing through Wikidata and that the main objective is to create a comprehensive and broad effect, to increase user competence and to integrate the platforms in various use cases. 


\section{Bibliography}

Bergmann, C. (2020). Die Coding da Vinci-Stipendien sind vergeben [Blog post]. Obtained from: https://blog.wikimedia.de/2020/02/14/die-coding-da-vinci-stipendien-sind-vergeben/.

Buchem, I., Franke, D., Kloppenburg, J., Liebert, R., Staub, M. (2015). Wiki Dialogues. A Concept for Digital Learning in Wikipedia Communities. Obtained from: https://commons.wikimedia.org/ wiki/File:Wiki_Dialogues__A_concept_for_digital_learning_in_Wikipedia_communities.pdf.

Education/Countries/Germany (2018). Outreach Wiki. Obtained from: https://outreach.wikimedia.org/w/index.php?title=Education/Countries/Germany\&oldid=179497.

German Wikibook. German Wikibook at a Glance (2019). Wikimedia Statistics (WikiStats). Obtained from: https://stats.wikimedia.org/wikibooks/EN/ReportCardTopWikis.htm\#lang_de; https://stats.wikimedia.org/wikisource/EN/ReportCardTopWikis.htm\#lang_de.

Mitarbeitende. Wikimedia Deutschland (2020). Obtained from: https://www.wikimedia.de/ mitarbeitende/.

Schmidt, E. (2013). TAO Collaborative Project. Sub-Project: TAO - Senior Knowledge. Obtained from: https://upload.wikimedia.org/wikipedia/commons/4/46/2013_TAO_final_report_ Silberwissen.pdf.

What is Coding da Vinci? Wikimedia Deutschland (2020). Obtained from: https://codingdavinci.de/about/.

Wikimedia Deutschland/Report on Educational Activities 2010-2012 (2013). Meta, Discussion About Wikimedia Projects. Obtained from: https://meta.wikimedia.org/w/index. php?title=Wikimedia_Deutschland/Report_on_educational_activities_2010-2012\&oldid=5633057.

Wikipedia: GLAM: https://de.wikipedia.org/wiki/Wikipedia:GLAM.

Wikiversity: Hochschulprogramm: https://de.wikiversity.org/wiki/Wikiversity:Hochschulprogramm.

\section{List of photographs}

Photo 1 Participants of the Coding DaVinci 2017 event (2017). Wladimir Raizberg (WMDE) / CC BY-SA (https://creativecommons.org/licenses/by-sa/4.0).

Photo 2 Sketchnote for the Natural History Museum, Berlin at the Coding DaVinci 2017 event (2017). Wladimir Raizberg (WMDE) / CC BY-SA (https://creativecommons.org/licenses/by-sa/4.0).

Photo 3 Seniors at the wiki-workshop in Cottbus. Silver Knowledge project (2017). Elvira Schmidt (WMDE) / CC BY-SA (https://creativecommons.org/licenses/by-sa/3.0). 
Nebojša Ratković, Paul Jerchel, Pen-Yuan Hsing, Klara Sielicka-Baryłka Wikipedia and Its Sister Projects...

\section{Pen-Yuan Hsing}

penyuanhsing@posteo.is

(iD https://orcid.org/0000-0002-5394-879X

Department of Mechanical Engineering

University of Bath

United Kingdom

\section{Teaching Citizenship and Academic Writing via Wikipedia in Higher Education, United States}

In undergraduate education, instructors often discourage the use of Wikipedia in research and academic writing. A common reason is that Wikipedia articles are unverified and unreliable. In other words, "Wikipedia is not always an accurate, updated reflection of the academy" (Mathewson 2017). While there is an element of truth to this assertion, Wikipedia is a valuable live demonstration of how knowledge is produced. In this short opinion piece, I will provide examples of that process based on work conducted by the Wiki Education organisation in integrating Wikipedia-editing into undergraduate teaching.

While traditional textbooks and academic journals continue to play a crucial role in education, Wikipedia shows that knowledge is not merely a static collection of facts. It is instead dynamic and subject to iterative improvement. A dramatic example was a prank initiated by the American talk show host Stephen Colbert, who, as a commentary on the lack of critical discourse in society, asked his viewers to disrupt Wikipedia articles (McGrady 2016). One edit asserted that the popularity of the French children's book character Babar the Elephant has tripled in popularity. Remarkably, this unsubstantiated claim was caught by Wikipedia editors and removed in less than

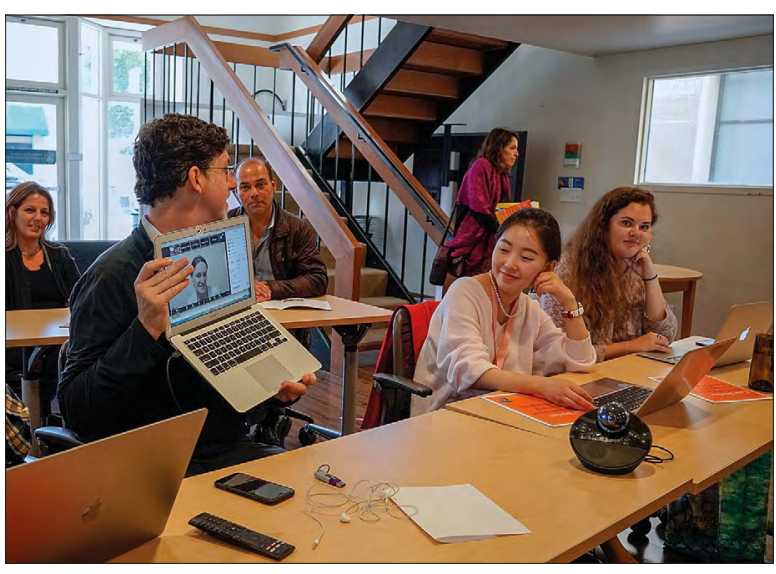
Photo 1 Wiki Education visits Middlebury Institute (2018) Joan E. Strassmann's behavioural

two minutes (Wikipedia contributors, 2006). Examples like this are recorded in each Wikipedia article's "Talk" and "View history" tabs. These tabs can reveal extensive editor discussions on the article, and a detailed, browsable history of every change that has been made to it. These features can be used in teaching, and allow one to examine the evolution of an article and how the peer review process can correct mistakes. For professor 
ecology course at Washington University Saint Louis in the United States, students learn about the behaviour of highly social insects such as bees. During the process, students are tasked with creating Wikipedia articles on the insect species they study. This contextualises the skills and knowledge they are learning, and in one semester 57 students edited 496 articles (343,000 words) that have been viewed 19.2 million times (https:// dashboard.wikiedu.org/courses/ Washington_University_in_St_Louis/ Behavioral_Ecology_Fall).

Creating Wikipedia articles is also used to practice interdisciplinary research and highlight diversity. For Marie Pellissier, a student of a Boston College history course, this meant a biographical article on Dr Susan LaFlesche Picotte, one of the first Native American women in the 19th century to become a physician in the United States, and an advocate for improved public health and rights of indigenous peoples (Salvaggio 2015). Additionally, writing this article required cross-disciplinary skills across history, writing, and medicine.

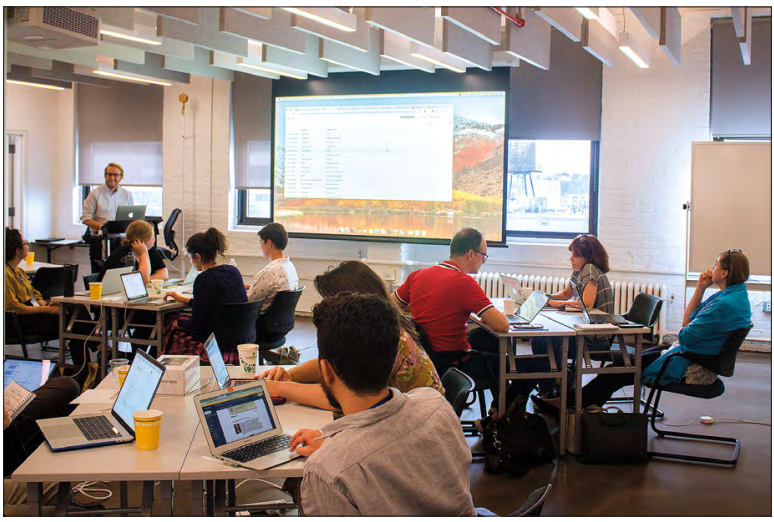

Photo 2 Wiki Education teaches Wikidata editing workshop in NYC (2018)

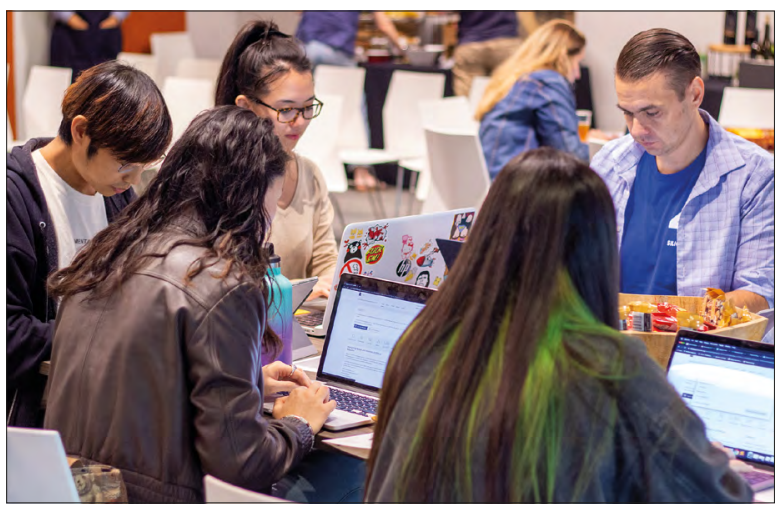

Photo 3 Attendees at an Ada Lovelace Wikithon (2019) assignments have an audience of one: the instructor. When the assignment is a Wikipedia article, the audience could be among the 500 million unique monthly visitors to the website (Mathewson 2017), and this has become a strong motivator for students. In one course, students reported that publishing on such an influential platform - with a readership of millions - engenders a strong sense of accountability and responsibility, more so than a traditional assignment (Vital 2017). This is reinforced by the active Wikipedia editing community which actively flags and removes unverified or unsubstantiated additions, encouraging students to critically evaluate sources of information and truthfully summarise them. Overall, the experience instilled 
pride in the students because their work lives beyond the classroom and will benefit a wide readership (McDowell 2017).

Additionally, the privilege of being in a university is access to books and journals normally locked behind paywalls that most non-academics cannot afford. By summarising that knowledge in articles, academics - including students - bring cutting-edge research into Wikipedia where so many depend on as a reliable source of information (Mathewson 2017).

Wiki Education (https://www.wikiedu.org/) is an initiative that coordinates and supports teachers in higher education to integrate Wikipedia-editing into classroom assignments. In addition to training modules on editing Wikipedia and manuals for instructors and students organized by discipline, there is also a course dashboard (https://dashboard.wikiedu.org/) that an instructor could customize to manage Wikipedia assignments. The examples above were all supported by Wiki Education, and since 2010 over 73,500 students from 500 North American universities have edited over 90,000 Wikipedia articles with more than 430 million views per academic term. In these times, I believe it is especially important to teach critical thinking and digital literacy in higher education, and the Wikipedia-editing can be an invaluable component in that effort.

Translated by Author

\section{Bibliography}

Mathewson, J. (2017). Wikipedia and the Quest for Legitimacy. Wiki Education. Obtained from: https://wikiedu.org/blog/2017/08/31/wikipedia-and-the-quest-for-legitimacy/.

McDowell, Z.J. (2017). Student Learning Outcomes Using Wikipedia-Based Assignments. Wiki Edu Foundation. Obtained from: https://commons.wikimedia.org/wiki/File:Student_Learning_ Outcomes_using_Wikipedia-based_Assignments_Fall_2016_Research_Report.pdf.

McGrady, R. (2016). Teaching Students to Separate Fact from Feeling in the Age of Truthiness. Wiki Education. Obtained from: https://wikiedu.org/blog/2016/12/28/separate-fact-from-feeling/.

Salvaggio, E. (2015). The Wikipedia Frontier. Wiki Education. Obtained from: https://wikiedu. org/blog/2015/01/22/wikipedia-frontier/.

Vital, S. (2017). Writing to Be Read, Not Just to Be Graded. Wiki Education. Obtained from: https://wikiedu.org/blog/2017/06/27/writing-to-be-read-not-just-to-be-graded/.

Wikipedia Contributors. (2006). Babar the Elephant. In Wikipedia. Obtained from: https://en.wikipedia.org/w/index.php?title=Babar_the_Elephant\&oldid=67099617. 


\title{
List of photographs
}

Photo 1 Wiki Education visits Middlebury Institute (2018). Samantha (Wiki Ed) / CC BY-SA (https://creativecommons.org/licenses/by-sa/4.0).

Photo 2 Wiki Education teaches Wikidata editing workshop in NYC (2018). Wiki Education / CC BY-SA (https://creativecommons.org/licenses/by-sa/4.0)

Photo 3 Attendees at an Ada Lovelace Wikithon (2019). Jami (Wiki Ed) / CC BY-SA (https://creativecommons.org/licenses/by-sa/4.0).

\author{
Klara Sielicka-Baryłka \\ klara.sielicka@wikimedia.pl \\ Wikimedia Polska \\ Poland
}

\section{Wikimedia Education - the Situation in Poland}

Wikimedia Education in Poland as a formalized department at Wikimedia Polska was only established in the fall of 2019. For years, however, educational activities went on continuously, responding to the current needs of users, institutions, educational institutions and project partners. In this situation, Wikimedia Polska see great value in substantive cooperation with the world movement Wikimedia Education - as a still-developing department of Wikimedia Polska, we take part in organized online meetings, where we learn about educational wiki-activities from other countries and share our experience. Wikimedia Polska also reports events and relevant information from ,our backyard' in an international newsletter. By extending the network of contacts within the wiki-ed movement, Wikimedia Polska can work better for education in Poland, including the perception and use of Wikipedia and its sister projects in the teaching and learning process.

The Wikipedia community knows best how to explain Wikipedia, how to create and improve it. That is why Wikimedia Polska constantly invite the Polish Wikipedia community to share successes and failures in wiki-educating and join Wikimedia Polska educational activities, for example through guest presentations and training for new users or for the teachers from the Wiki-school program. Wikimedia Polska also run a Wikipedian-in-Residence program in cultural institutions.

Wikimedia Polska is a member of the Open Education Coalition (pI KOED). It is a coalition of Polish non-governmental organizations and other institutions dealing with education, science, and culture, supporting the idea of 
developing and using open educational resources and acting for the legal accessibility of public scientific, educational and cultural heritage resources. In January 2020, the Coalition had 40 members.

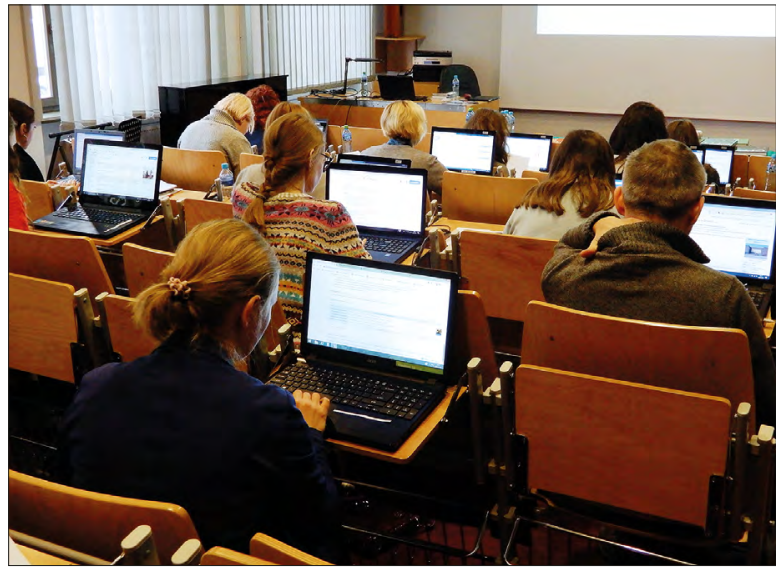

Photo 1 Wikipedia editing workshop as part of the 1lib1ref action at the Academy of Music in Katowice

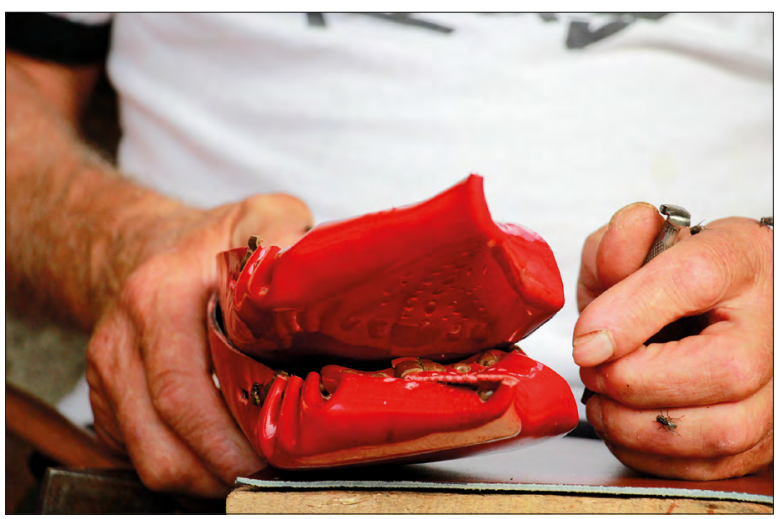

Photo 2 Documentation of making of moccasins of Muramares in the Gheorghe Roman's workshop. Romania Maramureș County, Bârsana. Carpathian Ethnography project

As part of educational activities, Wikimedia Polska promotes, supports, organizes or coordinates initiatives and activities such as:

\section{Training and competitions}

Characteristic for educational activities of Wikipedia are edit-a-thons, workshops, lectures on Wikipedia and its sister projects for cultural and educational institutions, libraries, schools, universities, etc. All of this is also present on the Polish agenda. Our community support department responds to the needs of coordinators of activities and invites experienced editors to conduct events, e.g. as part of the Open Education Week, supporting editing competitions (e.g. Wiki Science Competition, Wiki Loves Monuments or those in March, complementing gender gap on Wikipedia), etc.

\section{Action \# 1lib1ref and other activities of the Library Project}

The goal of the Library project is to better describe on Wikipedia all topics related to libraries, librarianship, library science, references, and related topics, as well as biographies of figures significant for Polish and world literature. We also want to develop encyclopedic criteria for librarians and libraries. \#1Lib1Ref is an annual international campaign encouraging librarians from around the world to join in the creation of Wikipedia, adding footnotes to reliable sources to the entries of the virtual encyclopedia. In 2020, thanks to Polish editors, Polish Wikipedia was ranked 7th in the world in terms of the number of footnotes added during the campaign. 


\section{Supporting GLAM-wiki activities}

Education, which understands the impact of open resources on the learning and teaching process, is education that also supports GLAM-wiki activities. For example, by promoting events and supporting the presence of experienced Wikipedians on edits organized by the Collective Kariatyda (as part of Art + Feminism initiative). Above all, Wikimedia Polska place great emphasis on promoting the use of GLAM resources in education, which in the Polish section of GLAM-wiki consists of 40,000, released' items from the collections and archives of many known museums and institutions.

\section{Educational projects in schools and universities}

School and academic projects (pI. PSiA) is a program designed for people and institutions related to education and science (mainly primary and secondary schools). Experienced Wikipedia members help participants publish new material on Wikipedia. The project website maintains documentation of classes (list of participants, list of entries, etc.), there is also a section of help materials and numerous tips and advice. Some Wikipedia classes are short-term, while others continue for years thanks to the involvement of Wikipedia teachers - the school's teachers and favorable management.

In turn, the \#EtnoWiki project is addressed to universities, and more specifically to the Faculties of Ethnology and Cultural Anthropology present at Polish universities. The \#EtnoWiki project, focusing on tasks related to the creation, correction, supplementation, and translation into Polish of entries of cultural anthropology, ethnology, and ethnography. Activities undertaken as part of the EtnoWiki initiative are not only edit-a-thons and organization of semester focused on the creation of new articles at specific universities. Very important is field activity so crucial in the work of an ethnographer. Former projects such as 'Ritual Year with Wikipedia' and 'Ethnography of the Carpathians' are case studies for many now and ethno-walks are very popular, too.

\section{Wiki-school project}

Wiki-school program is the main element of the new educational strategy at Wikimedia Polska. The main goal is to make a certain number and type of schools introduce (ideally: permanently) into the educational program focused on the theory and practice of Wikipedia and its sister projects (Wikisource, Wikitonary, Wikimedia

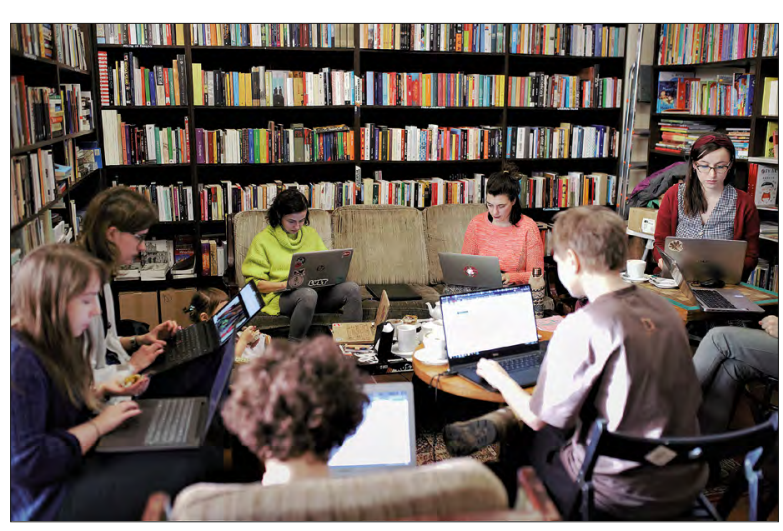

Photo 3 Edit-a-thon with Caryatid Collective 
Commons and others). It will be built on the basis of a new model of cooperation developed by Wikipedia members together with teachers. 14 schools from various cities in Poland applied for the project. Each of the schools is represented by the leader - here are primarily Polish Literature teachers: enthusiasts of using ICT tools in education and modern teaching methods, recognized authors of textbooks, award-winning educators and educational bloggers. As part of the strategy, the specific objectives of the program have been formulated:

- Objective 1 Creating participatory methods of educational tools for conducting pilot lessons/classes on digital competences using Wikipedia in Polish language classes and / together - IT and/or history;

- Objective 2 To increase knowledge and significantly increase teachers' competence in teaching key digital competences;

- Objective 3 Strengthening pro-social attitudes in student communities and teaching staff participating in the school program;

- Objective 4 The permanent presence of grafted knowledge and tools in the school's program and ecosystem.

The project started in March 2020.

\section{6. $\quad$ Living Tradition on Wikipedia}

At the beginning of March 2020, we also announced the start of an education and research project entitled "Living tradition on Wikipedia". The National Heritage Institute in Poland (NID) and Wikimedia Polska with the significant participation of wiki-mentors want to increase the visibility of intangible cultural heritage in Wikimedia projects. One of the objectives of the project is to create bottom-up documentation and heritage inventory for communities, groups and individuals who are its depositaries. For this, Wikimedia Polska will use tools and possibilities, including Wikimedia Commons. Project coordinators are convinced that Wikipedia and its sister projects can become tools for the independent transfer of knowledge about cultural heritage, complementing the intergenerational message, and responding to threats in the protection of intangible heritage, among which UNESCO indicates:

- the reduced interest of the young generation;

- suppression of transmission;

- changes caused by globalization of culture, new products, and technologies.

This project is to show that new technologies do not have to be a threat but can be a recipe for a weakened message. This is the first such initiative in Poland regarding the UNESCO Convention of 2003. 


\section{Bibliography}

Caryatid Collective (pl Kolektyw Kariatyda): https://pl.wikipedia.org/wiki/Wikiprojekt:GLAM/ Kolektyw_Kariatyda.

Jemielniak, D. (2013). Życie wirtualne dzikich. Netnografia Wikipedii, największego projektu współtworzonego przez ludzi. Warszawa: Wydawnictwo Poltex.

Pacewicz, A., Ptaszek, G. (2019) (red.). Model Edukacji Medialnej, Informacyjnej i Cyfrowej (MEMIC). Kraków-Warszawa. Obtained from: https://fina.gov.pl/wp content/uploads/2019/12/ memic_publikacja.pdf.

Ritual Year with Wikipedia: https://pl.wikimedia.org/wiki/Plik:Ritual_year_with_Wikipedia.pdf.

UNESCO Convention. Inventories: Identifying for Safeguarding: https://ich.unesco.org/en/ inventorying-intangible-heritage-00080.

Villeneuve, C. (2019). Academia is Changing its Mind About Wikipedia. Obtained from: https:// wikiedu.org/blog/2019/08/13/academia-is-changing-its-mind-about-wikipedia/.

Wikiproject: Education (pl Wikiprojekt Edukacja): https://pl.wikipedia.org/wiki/Wikiprojekt:Edukacja. Wikiproject: EtnoWiki (pl Wikiprojekt: EtnoWiki): https://pl.wikipedia.org/wiki/Wikiprojekt:EtnoWiki. Wikiproject: GLAM (pl Wikiprojekt:GLAM): https://pl.wikipedia.org/wiki/Wikiprojekt:GLAM. Wikiproject: Library (pl Wikiprojekt: Biblioteka): https://pl.wikipedia.org/wiki/Wikiprojekt:Biblioteka. Wikiproject: Living heritage on Wikipedia (pI Wikiprojekt: Żywa tradycja W Wikipedii): https:// pl.wikipedia.org/wiki/Wikiprojekt:Edukacja/\%C5\%BBywa_tradycja_W_Wikipedii.

Wikiprogram Schools \& Academias projects (pl projekt Projekty szkolne i akademickie): https:// pl.wikipedia.org/wiki/Wikipedia:Projekty_szkolne_i_akademickie.

Wikiproject: Wiki-school (pl Wikiprojekt: Wikiszkoła): https://pl.wikipedia.org/wiki/ Wikiprojekt:Edukacja/Projekt_Wiki-szko\%C5\%82a.

Unknown Women of Wikipedia - Contest Site (pl (Nie)znane kobiety Wikipedii): https://pl.wikipedia.org/wiki/Wikipedia:(Nie)znane_kobiety_Wikipedii.

\section{List of photographs}

Photo 1 Wikipedia editing workshop as part of the 1lib1ref action at the Academy of Music in Katowice. EwkaC / CC BY-SA (https://creativecommons.org/licenses/by-sa/4.0).

Photo 2 Documentation of making of moccasins of Muramares in the Gheorghe Roman's workshop. Romania Maramureș County, Bârsana. Carpathian Ethnography project. Mariusz Raniszewski / CC BY-SA (https://creativecommons.org/licenses/by-sa/4.0).

Photo 3 Edit-a-thon with Caryatid Collective. Celina Strzelecka / CC BY-SA (https://creativecommons.org/licenses/by-sa/4.0). 


\section{Conclusion}

During the coronavirus pandemic, when schools closed the doors in most countries, the Wikimedia Education Team took the position quickly and with full commitment. The \#EduWiki challenge has started and the main declaration brings up goals like curate and share widely the resources produced by our Wikimedia \& Education community; foster knowledge sharing about the impact of COVID-19 on Education; support the UNESCO COVID-19 Education Coalition. Many Wikimedia Education chapters around the world have joined in these activities.

The same commitment and awareness of how Wikipedia and its projects are great at developing digital competences and learning skills is demonstrated by examples from the educational teams of several Wikimedia chapters: Serbia, Germany, the USA and Poland. Open education activities are just as important in times of crisis as in peacetime.

\section{Bibliography}

Edukacja zdalna w czasie pandemii - raport z badań (2020). Obtained from: https://centrumcyfrowe.pl/edukacja-zdalna/.

Global Education Coalition - COVID-19 Education Response. Obtained from: https://en.unesco. org/covid19/educationresponse/globalcoalition.

Impact of the 2019-20 Coronavirus Pandemic on Education. Obtained from: https://en.wikipedia.org/wiki/Impact_of_the_2019\%E2\%80\%9320_coronavirus_pandemic_on_education.

\section{Summary}

The article presents the general idea of Wikimedia education and the situation of educational programs based on Wiki(p)media tools and capabilities in four countries.

Key words: Wikipedia, Wikimedia, education, Wikimedia Education, GLAM, GLAM-wiki, libraries, open education, teaching, learning, Serbia, Germany, United Kingdom, Poland

\section{Streszczenie}

Artykuł przedstawia ogólną ideę ruchu Wikimedia Education oraz sytuację programów edukacyjnych opartych na narzędziach i możliwościach Wiki (p)media w czterech krajach.

Słowa klucze: Wikipedia, Wikimedia, edukacja, Wikimedia Education, GLAM, GLAM-wiki, EtnoWiki, biblioteki, otwarta edukacja, uczenie się, nauczanie, Serbia, Niemcy, Wielka Brytania, Polska

Tłumaczenie: Klara Sielicka-Baryłka 